Brytyjska” następuje „Lending Division”, a po nim „Biblioteka Cambridge University”. Ostatnie słowo krytyki należy się konstrukcji tabel nr 2-4 oraz 7-10, które nie konfrontują dwóch cech i są w istocie alfabetycznymi wyliczeniami. Powoduje to bezskuteczne próby poszukiwania ukrytego sensu konstrukcji tych tabel, którego w istocie nie ma.

Lista uchybień redakcyjnych jest długa, ale to przede wszystkim nowatorski charakter książki daje nadzieję na rychłe drugie wydanie Światowego modelu informacji bibliograficznej. Bo nie można wątpić, że będzie ono potrzebne - nakład tej pozycji, z uwagi na świetny poziom merytoryczny oraz zaspokojenie potrzeby nowej refleksji w nauce o bibliografii, powinien zostać szybko wyczerpany, gdyż można ją polecić wszystkim, którzy interesują się nowoczesną bibliografią.

Jakub Maciej Łubocki
Instytut Informacji Naukowej i Bibliotekoznawstwa, Uniwersytet Wroctawski

Nadestano: 25 lutego 2016.

\title{
Mariusz Jarocki: Open Source w bibliotekach w świetle badań publicznych uczelni akademickich $w$ Polsce. Torun: Wydaw. Naukowe Uniwersytetu Mikołaja Kopernika, 2015, ss. 300. ISBN: 978-83-231-3479-4
}

Książka Mariusza Jarockiego pt. Open Source w bibliotekach w świetle badań publicznych uczelni akademickich $w$ Polsce jest jedną z niewielu polskich publikacji traktujących o zjawisku Otwartego Źródła w kontekście działalności instytucji bibliotecznych. Książka stanowi skróconą wersję dysertacji doktorskiej noszącej tytuł Zastosowania oprogramowania Open Source w bibliotekach publicznych uczelni akademickich $w$ Polsce obronionej w 2014 r. na Wydziale Nauk Historycznych UMK w Toruniu. Warto zaznaczyć, że wydana drukiem praca to także pierwsza publikacja z zakresu bibliologii i informacji naukowej, która koncentruje się nie tylko na genezie i historii oprogramowania Open Source, jego charakterystyce, ale stanowi przede wszystkim przejrzyste kompendium wiedzy na temat możliwych do zastosowania - zwłaszcza w uczelnianych bibliotekach - tworzonych w ramach tego zjawiska aplikacji. Dodajmy, że w 2014 r. nakładem Wydawnictwa SBP ukazała się praca Sebastiana D. Kotuły pt. Wstęp do Open Source, będąca syntetycznym wprowadzeniem do zagadnienia Open Source, także z perspektywy problemów będących częścią informatologii i bibliologii. Książka M. Jarockiego jest doskonałym rozwinięciem tez i charakterystyk przygotowanych przez S. D. Kotułę, ujętym z punktu widzenia systemów i aplikacji przeznaczonych dla działalności bibliotek. Nie będzie chyba nadużyciem, jeśli stwierdzę, że te dwie prace uzupełniają się wzajemnie. Książka S. D. Kotuły przybliża genezę, historię ruchu Open Source, zawiera szczegółową charakterystykę oprogramowania (także z punktu widzenia porównań z komercyjnymi rozwiązaniami programistycznymi). Jest źródłem informacji dla osób chcących nabyć wstępną wiedzę na temat wybranych informatycznych rozwiązań. Stanowi, jak zaznacza zresztą sam autor, wprowadzenie do zagadnienia Open Source w ogóle. W przypadku pracy M. Jarockiego, mamy natomiast do czynienia z bardziej szczegółową charakterystyką różnorodności oprogramowania, przedstawioną z perspektywy jego wykorzystania w poszczególnych procesach bibliotecznych, zarówno podstawowych, jak i pomocniczych. Co więcej, intencją autora recenzowanej pracy było przygotowanie wskazówek dla bibliotek, które swoje działania oparły właśnie na systemach otwartych. W związku z tym M. Jarocki, na podstawie przeprowadzonych badań i analiz, nie tylko ukazał schemat aktualnego wykorzystania otwartego oprogramowania w badanych jednostkach, ale zaprezentował 
także własną propozycję modelu automatyzacji działania biblioteki publicznej uczelni akademickiej w oparciu o rozwiązania bezpośrednio odnoszące się do omawianego w pracy zjawiska. Model ten stanowi przy tym wskazówkę dotyczącą możliwości wykorzystania różnego typu oprogramowania z perspektywy wykonywanych w bibliotece działań. Celem rozprawy doktorskiej była więc analiza rynku i wdrożenia poszczególnych programów oraz systemów z punktu widzenia działalności polskich książnic. Na podstawie własnych obserwacji i przeglądu poszczególnych narzędzi autor pokazał także, w których obszarach tej działalności otwarte programy i systemy mają najczęstsze zastosowanie. M. Jarocki skupił się na funkcjonowaniu polskich bibliotek publicznych uczelni akademickich. Powody takiego wyboru są jak najbardziej zrozumiałe. W bibliotekach tego typu, na tle wszystkich instytucji książki, komputeryzacja została przeprowadzona stosunkowo najwcześniej. Co więcej, zazwyczaj posiadają one w swojej strukturze organizacyjnej dział ds. komputeryzacji lub informatyzacji, w którym zatrudnione są osoby posiadające odpowiednie kompetencje w zakresie instalacji, konfiguracji i administracji poszczególnymi otwartymi systemami czy programami. Jest to bardzo ważny argument. Instytucje te, pomimo, że korzystają z oprogramowania z otwartym kodem źródłowym, muszą brać pod uwagę trudności związane z samą implementacją i występującymi w późniejszym czasie problemami w użytkowaniu poszczególnych programistycznych rozwiązań. W tym przypadku mamy do czynienia z sytuacją, kiedy dostęp do aplikacji czy systemów Open Source jest najczęściej bezpłatny, ale prace mające na celu ich wdrożenie i wykorzystanie zawsze generują pewne koszty. M. Jarocki zastanawia się przy tym nad intensywnością wykorzystania tego typu rozwiązań przez biblioteki publicznych uczelni akademickich. Stawia też tezę, że większość tych instytucji implementuje i wykorzystuje aplikacje Open Source głównie jako wsparcie pomocniczych procesów bibliotecznych. Podstawowe procesy (gromadzenie zbiorów, budowanie katalogów, opracowanie dokumentów, udostępnianie zasobów, wyszukiwanie i przekazywanie informacji) są wspierane przez oprogramowanie Open Source tylko w największych tego typu placówkach. Należy zaznaczyć, że autor wziął pod uwagę oprogramowanie działające w oparciu o systemy Windows i Linux, a pominął system Mac OS. Powodem takiej decyzji była mała - według autora - popularność tego systemu w Polsce. Jednak wydaje się, że urządzenia oferowane przez firmę Apple również w naszym kraju są wykorzystywane przez coraz większą liczbę użytkowników. Wiele na to wskazuje, że w najbliższych latach firma ta może także stać się jednym z głównych graczy na polskim rynku informatycznym i komputerowym. Oferowane przez nią tablety już dzisiaj są wykorzystywane przez pracowników bibliotek i czytelników na przykład w ramach realizowanego przez Fundację Rozwoju Społeczeństwa Informacyjnego projektu „Tablety w Twojej Bibliotece” (w 2015 r. przekazano ponad 1250 tabletów iPad 318 bibliotekom).

Recenzowana książka składa się z czterech głównych części, które zostały przygotowane z punktu widzenia analizowanych i charakteryzowanych w pracy problemów. Pierwsza, najkrótsza część, dotyczy samego zjawiska Open Source - jego genezy, definicji najważniejszych terminów oraz historii ewolucji społeczności tego ruchu. Autor słusznie wskazał na dwa, z pozoru bardzo podobne terminy wolne oprogramowanie oraz oprogramowanie o otwartym kodzie źródłowym. W przypadku tego drugiego, nie do końca prawidłowo został przetłumaczony tytuł pierwszego warunku, który musi być spełniony, aby program mógł być uważany za Open Source. Chodzi mianowicie o zasadę, która w definicji Otwartego Źródła w języku angielskim brzmi free redistribution. Nie chodzi tutaj jednakże o darmową, ale wolną redystrybucję, tzn. licencja nie może wprowadzać zakazów dotyczących sprzedaży lub darmowego przekazywania oprogramowania jako części pewnej całości. Dobrze ten mankament wyjaśnia S. D. Kotuła we wcześniej wspomnianej książce. M. Jarocki słusznie natomiast wskazał na różnice pomiędzy oprogramowaniem należącym do tzw. free software a rozwiązaniami typu Open Source. Niuanse wynikające z tego porównania wydają się być źródłem częstych błędów popełnianych przez osoby, które niedokładnie rozumieją istotę zjawisk dotyczących otwartości w dzisiejszym udostępnianiu, a może nawet bardziej dzieleniu się różnego typu cyfrowymi wytworami, w tym aplikacjami stworzonymi czy współtworzonymi w ramach współpracy użytkowników. 
Słuszne wydaje się także wskazanie wad oprogramowania Open Source, szczególnie z punktu widzenia kosztów wdrożenia, wsparcia i serwisu dla użytkownika końcowego. Przydatny dla zainteresowanego tym zjawiskiem czytelnika okaże się na pewno wykaz źródeł informacji dotyczących społeczności skupionych wokół poszczególnych projektów, w tym zwłaszcza krótkie charakterystyki serwisów i portali związanych z ruchem Open Source.

Druga i trzecia część książki dotyczy systemów przeznaczonych do automatyzacji procesów bibliotecznych. Znajdziemy tutaj szczegółowy wykaz i syntetyczną charakterystykę przywołanych przez autora rozwiązań. Drugi rozdział koncentruje się na podstawowych procesach bibliotecznych, w tym, oczywiście, tych dotyczących gromadzenia, opracowania i udostępniania zbiorów. M. Jarocki przedstawia najczęściej wykorzystywane i na potrzeby pracy sprawdzone rozwiązania (z pominięciem programów nieaktualizowanych lub przygotowanych dla systemu Mac OS). Źródłem wiedzy służącej znajdowaniu informacji o oprogramowaniu były dla autora: fachowa literatura przedmiotu oraz specjalistyczne serwisy internetowe bezpośrednio powiązane z problematyką Open Source i rozwiązaniami programistycznymi wdrażanymi w bibliotekach. W opisie zastosowanej metodologii brakuje jednak informacji na temat kwerend odnoszących się do prowadzonych poszukiwań wykorzystanej literatury. Autor korzystał zapewne z różnego rodzaju baz pełnotekstowych czy cyfrowych repozytoriów i bibliotek. Przydałoby się je tutaj przynajmniej wymienić. Tym bardziej, że w tekście książki pojawia się informacja o doborze oprogramowania m.in. na podstawie prostych zapytań zadanych za pośrednictwem wyszukiwarki Google.

Rozdział drugi, dotyczący systemów przeznaczonych dla podstawowych procesów bibliotecznych został podzielony na cztery podrozdziały, w których autor przedstawił informacje na temat oprogramowania, które może być wykorzystywane przez biblioteki w ich codziennych pracach. Znajdziemy więc tutaj charakterystykę zintegrowanych systemów bibliotecznych, oprogramowania do zarządzania zasobami cyfrowymi czy wspierającego procesy wyszukiwania dokumentów. Na szczególną uwagę zasługuje zwłaszcza charakterystyka platform i programów służących do budowy cyfrowych bibliotek i repozytoriów. Nie ukazała się do tej pory w języku polskim żadna inna publikacja, która zawierałaby bardziej kompletną bazę informacji dotyczących oprogramowania Open Source przeznaczonego do prezentacji i zarządzania kolekcjami cyfrowymi. W przypadku zautomatyzowanych systemów bibliotecznych, na uwagę zasługują zwłaszcza charakterystyki popularnych dzisiaj systemów Evergreen i Koha. Przydałoby się jednak nieco więcej informacji odnoszących się do wdrożeń Koha w polskich instytucjach. Jest ich dzisiaj całkiem sporo, nie tylko zresztą w przypadku bibliotek akademickich. W tym rozdziale książki M. Jarocki posłużył się jedynie kilkoma przykładami wdrożeń z bibliotek zagranicznych. Ciekawie za to prezentuje się podrozdział dotyczący narzędzi wspierających proces wyszukiwania dokumentów udostępnianych w bibliotekach. Autor przedstawił poszczególne rozwiązania słusznie zresztą przyporządkowując je do trzech rodzajów programów (narzędzi indeksujących, katalogów OPAC oraz interfejsów informatyczno-wyszukiwawczych). Dobrym uzupełnieniem rozważań na temat narzędzi wspierających podstawowe procesy biblioteczne jest podrozdział dotyczący zarządzania bibliografią i cytowaniami. M. Jarocki skupił się przy tym na dwóch typach rozwiązań: bibliograficznych bazach danych oraz programach umożliwiających zarządzanie informacją bibliograficzną i cytowaniami. Zwłaszcza to drugie rozwiązanie jest dzisiaj coraz częściej postrzegane jako istotne wsparcie prac mających na celu gromadzenie i łatwe zarządzanie informacjami o dokumentach, ale także - samymi dokumentami. Aspekt ten może też dotyczyć możliwości tworzenia przez użytkownika swoistej osobistej elektronicznej biblioteki złożonej z wyselekcjonowanych przez niego cyfrowych zasobów. Co więcej, oprogramowanie to służy z jednej strony, do zarządzania zgromadzonymi informacjami bibliograficznymi oraz zapewnienia jednolitego formatu cytowania w przygotowywanych dokumentach tekstowych (np. z wykorzystaniem edytora Microsoft Word), jak również do dzielenia się gromadzonymi danymi z innymi użytkownikami i łatwej współpracy przy tworzeniu tematycznych zbiorów informacji bibliograficznych. Takie możliwości oferuje na przykład charakteryzowane przez M. Jarockiego Zotero, program będący jednocześnie 
usługą sieciową wykorzystywaną przez użytkowników z różnych stron świata w celu zarządzania gromadzoną przez nich informacją bibliograficzną.

Trzeci rozdział książki dotyczy szerokiego spektrum oprogramowania Open Source, które może być wykorzystane do realizacji bibliotecznych procesów pomocniczych. Poszczególne systemy i aplikacje zostały przyporządkowane do pięciu kategorii rozwiązań. M. Jarocki zwrócił więc tutaj szczególną uwagę na systemy operacyjne, bazy danych, języki programowania, systemy zarządzania treścią oraz wybrane aplikacje użytkowe ( $\mathrm{w}$ tym pakiety biurowe, aplikacje wspierające pracę $\mathrm{z}$ plikami graficznymi, muzycznymi, wideo, komunikatory internetowe, przeglądarki internetowe itp.). Ta część pracy jest najbardziej ogólna, tzn. w swojej istocie omawiane rozwiązania najmniej koncentrują się na działalności bibliotek. Jednakże, ze względu na szeroki wachlarz możliwości wykorzystania omawianego oprogramowania, także z punktu widzenia przetwarzania multimedialnych dokumentów, komunikacji czy zarządzania i administracji pracy instytucji bibliotecznych, rozdział ten stanowi najobszerniejszą część recenzowanej książki. Popularność i dostępność różnorodnych rozwiązań informatycznych dotyczących zjawiska Open Source utrudniały zapewne wybór oprogramowania poddanego przez autora dalszym analizom. M. Jarocki oprócz wyszukiwania danych za pośrednictwem najpopularniejszej wyszukiwarki, kwerend w fachowej literaturze czy specjalistycznych serwisach internetowych gromadzących informacje o programach Open Source, posłużył się w tym celu autorską ankietą, której wyniki szczegółowo zostały przedstawione w ostatnim rozdziale książki (Oprogramowanie Open Source w bibliotekach publicznych uczelni akademickich $w$ Polsce - wyniki autorskich badań ankietowych). Przedmiotem tych badań, jak wskazuje autor, „były wybrane aspekty technologii informatycznej wspierającej usługi i procesy zachodzące w publicznych bibliotekach akademickich". Wśród tez badawczych postawionych przez M. Jarockiego znajdują się założenia dotyczące częstotliwości i popularności wykorzystania poszczególnych rozwiązań, wpływu na korzystanie z nich czynnika finansowego, jak również tezy odnoszące się do kwestii edycji, współtworzenia i przystosowania przez bibliotekarzy do swoich potrzeb kodu źródłowego oprogramowania. Autor słusznie założył, że większość planowanych wdrożeń programów Open Source w bibliotekach jest powiązana $\mathrm{z}$ udostępnieniem wprowadzanych usług w trybie online. Zrozumiałe wydaje się też założenie dotyczące wdrażania projektów Open Source w kontekście wykorzystywania systemów informacyjnych, narzędziowych czy systemów operacyjnych (serwerowych).

Jak wcześniej wspomniano, aby zweryfikować postawione tezy, autor posłużył się metodą sondażu diagnostycznego, a kwestionariusz wykorzystanej w nim ankiety jest zamieszczony na końcu książki. Warto zaznaczyć, że M. Jarocki oprócz rozsyłania ankiet drogą elektroniczną, wykorzystał także technikę wywiadu i bezpośredni kontakt z wybranymi pracownikami bibliotek. Przy czym prowadzący badanie, $\mathrm{z}$ różnych względów, także tych dotyczących bezpieczeństwa bibliotecznych systemów, słusznie skorzystał z anonimowej formy udostępniania ankiet. Na treść ankiety składały się pytania otwarte, półotwarte oraz zamknięte, co umożliwiło autorowi przeprowadzanie analiz ilościowych i jakościowych. Bardzo istotny był także podział ankiety na trzy części, z których jedna była skierowana do osób w ogóle nie wykorzystujących rozwiązań Open Source. Obiektem badań były największe biblioteki akademickie w Polsce (odpowiedzi udzieliło 55 instytucji), w których, jak się okazało w trakcie badania, rozwiązania Open Source są rzeczywiście popularne. Nie jest też zaskoczeniem, że większość bibliotek wybiera je ze względu na niższe koszty wdrażania oraz brak konieczności przeprowadzania procedury przetargowej. Potwierdziła się też teza autora, że najczęściej wykorzystywane jest oprogramowanie użytkowe i narzędziowe, choć znajdziemy też przypadki implementacji zintegrowanych systemów bibliotecznych, tworzenia na bazie tych rozwiązań bibliotek cyfrowych, repozytoriów czy platform e-learningowych. Większość bibliotekarzy uważa również, że idea ruchu Open Source znajduje zrozumienie w środowisku bibliotekarskim, a wdrażanie w bibliotekach towarzyszących jej informatycznych rozwiązań wydaje się dzisiaj niezbędne.

Książka M. Jarockiego to bardzo ważna pozycja na rynku wydawniczym. Bez wątpienia ma duże znaczenie zarówno dla wyjaśnienia czym jest samo zjawisko Open Source, jak i dla poznania 
możliwości oferowanych dzisiaj przez oprogramowanie tego typu instytucjom bibliotecznym. Polskie środowisko bibliotekarskie i naukowe czeka na tego typu opracowania aktualnych i kluczowych dla bibliotek zagadnień. Nie mam co do tego żadnych wątpliwości. Szybka ewolucja nowych technologii i towarzyszących im zjawisk powoduje konieczność ciągłego przygotowywania przez badaczy zarówno teoretycznych, jak i także praktycznych kompendiów wiedzy.

Praca nie posiada niestety indeksu. Jestem przekonany, że byłby on doskonałym uzupełnieniem treści, bardzo przydatnym dla czytelników. Książka, co ważne, dostępna jest w wersji elektronicznej, m.in. w wirtualnej czytelni iBuk Libra, z której korzysta dzisiaj duża liczba polskich bibliotek.

Reasumując, wartość pracy M. Jarockiego oceniam bardzo wysoko. Książka jest doskonałym źródłem wiedzy dla osób poszukujących informacji na temat zjawiska Open Source, jak i przykładów funkcjonalnego i użytecznego dla bibliotek oprogramowania. Może też w przyszłości stanowić materiał porównawczy dla podobnych analiz.

Grzegorz Gmiterek

Katedra Bibliografii i Dokumentacji

Wydziat Dziennikarstwa, Informacji i Bibliologii

Uniwersytetu Warszawskiego

Nadestano: 21 lipca 2016.

Małgorzata Kowalska: Crowdsourcing internetowy - pozytywny wymiar partycypacji społecznej. Konteksty - istota - uwarunkowania. Warszawa: Wydaw. SBP, 2016, ss. 366. Seria „Nauka, Dydaktyka, Praktyka”; 165. ISBN 978-83-64203-60-2

Znacząco rośnie liczba naukowych tekstów z różnych dziedzin wiedzy, w których pojawiają się takie określenia jak: zbiorowa inteligencja, mądrość tłumu, inteligencja współpracy, wikinomia, otwarta innowacja, prosumpcja, crowdsourcing, crowdfunding, produkcja partnerska i in. Podkreśla się w nich pewien wymiar nowej ekonomii, przede wszystkim aspekt biznesowy i marketingowy.

Książka Małgorzaty Kowalskiej - Crowdsourcing internetowy - pozytywny wymiar partycypacji społecznej. Konteksty - istota - uwarunkowania, wydana przez Stowarzyszenie Bibliotekarzy Polskich, jest włączeniem się w żywo toczący się naukowy dyskurs dotyczący kierunków rozwoju nowoczesnych społeczeństw, w których nie same technologie, lecz ich inteligentne użycie zdecyduje o ich kondycji. Na tle innych publikacji, dotyczących partycypacyjnego modelu współpracy użytkowników sieci, monografię M. Kowalskiej odróżnia staranne uporządkowanie i doprecyzowanie zakresów znaczeniowych wielu terminów powiązanych z prezentowanym fenomenem, a także ulokowanie szeroko zakrojonej tematyki crowdsourcingu w obszarze bibliologii i nauki o informacji.

Wybór tematu badań należy uznać za bardzo trafny, szczególnie w okresie konwergencji mediów i kształtowania się wzorów zachowań społecznych nowych stechnicyzowanych społeczeństw. Znacząco rośnie bowiem zainteresowanie inicjatywami angażującymi ochotników z sieci. Potwierdza to wzrastająca liczba ukazujących się na ten temat publikacji, jak i analiza zapytań kierowanych z hasłem „crowdsourcing” do wyszukiwarki Google, na co wskazuje także autorka.

Książka została starannie przemyślana, co odzwierciedla kompozycja i ujęcie rozprawy. M. Kowalska podzieliła tekst na dwie zasadnicze części: część I. Otoczenie crowdsourcingu jest wprowadzeniem i bazą do części II. skupiającej się na wyjaśnieniu samego fenomenu crowdsourcingu.

Zarówno technologiczne, jak i ekonomiczne otoczenie crowdsourcingu oraz jego społeczne i kulturowe konteksty zanalizowane przez autorkę w części pierwszej prowadzą do wyjaśnienia warunków sprzyjających powstawaniu nowych modeli partycypacji społecznej. Śledząc rozwijanie 